\title{
KONSEP MUHAMMAD SHAHRU TENTANG AURAT PEREMPUAN
}

\author{
Laila Nurul hidayah \\ IAIN Ponorogo \\ akmalfaizalatif@gmail.com
}

\begin{abstract}
Abstrak
In Islam, clothing does not only function as jewelry and body armor from heat and cold, but more importantly is to cover the nakedness. Al-Qur'an al-Karim shows the obligation of women to cover their bodies in His words, "And let them not show their jewels, except those which (normally) appear from them, ". Parts offemale limbs that are not allowed to be seen by others are aurat. Islamic scholars agree that all women's bodies are aurat, in addition to the face and two palms. What is meant by the jewelry that appears is the face and two palms. While what is meant by khimar is a headgear, not a face covering like a veil, and what is meant by jaib is chest. The women have been ordered to put a cloth over his head and spread it to cover her chest. By doing library research, that is, research whose main object is books or other sources of literature, meaning that data is sought and found through literature review of books relevant to the discussion, a minimum limit of aurat according to Muhammad Shahrur is that dress cover the juyub, while the maximum limit is dressing which covers all parts of the body besides the face and palms.
\end{abstract}

Keywords: Limit, Khimar, and Aurat

Dalam Islam busana tidak hanya berfungsi sebagai perhiasan dan pelindung tubuh dari panas dan dingin, tapi yang lebih utama adalah untuk menutupi aurat. Al-Qur'an al-Karim menunjukkan kewajiban wanita untuk menutupi tubuhnya dalam firman-Nya, "Dan janganlah mereka menampakkan perhiasannya, kecuali yang (biasa) tampak darinya,". Bagian anggota badan wanita yang tidak diperbolehkan dilihat oleh orang lain, ulama madzhab sepakat bahwa semua badannya adalah aurat, selain muka dan dua telapak tangannya, yang dimaksud dengan perhiasan yang nampak itu adalah muka dan dua telapak tangan. Sedangkan yang dimaksud dengan khimar adalah tutup kepala, bukan penutup muka dan yang dimaksud jaib adalah dada. Para wanita itu telah diperintahkan untuk meletakkan kain penutup di atas kepalanya dan melebarkannya sampai menutupi dadanya.

Penelitian ini adalah Jenis penelitian kepustakaan (library research), yaitu penelitian yang obyek utamanya adalah buku-buku atau sumber kepustakaan lain, maksudnya data-data dicari dan ditemukan melalui kajian pustaka dari buku yang relevan dengan pembahasan. Sumber data yang dijadikan bahan-bahan dalam kajian ini merupakan sumber data yang diperoleh dari bahan-bahan pustaka yang dikategorikan sebagai berikut: Sumber data primer, Sumber data sekunder. Sedangkan proses dalam jenis penelitian ini adanya Teknik pengumpulan data, Analisis data.

Diakhir penulisan penelitian ini batas minimal aurat menurut Muhammad Shahrur yaitu berpakaian yang menutupi bagian juyub saja (daerah dada yang terbuka + bawah ketiak + kemaluan + pantat), sedangkan batas maksimalnya berpakaian yang menutupi seluruh bagian tubuh selain wajah dan kedua telapak tangan.

Kata kunci: Batas, Khimar dan Aurat 


\section{Pendahuluan}

Busana dalam Islam tidak hanya berfungsi sebagai perhiasan dan pelindung tubuh dari panas dan dingin, tapi yang lebih utama adalah untuk menutupi aurat. ${ }^{1}$ Al-Qur'an al-Karim menunjukkan kewajiban wanita untuk menutupi tubuhnya dalam firman-Nya, "Dan janganlah mereka menampakkan perhiasannya, kecuali yang (biasa) tampak darinya," 2 . Bagian anggota badan wanita yang tidak diperbolehkan dilihat oleh orang lain, ulama madzhab sepakat bahwa semua badannya adalah aurat, selain muka dan dua telapak tangannya, yang dimaksud dengan perhiasan yang nampak itu adalah muka dan dua telapak tangan. Sedangkan yang dimaksud dengan khimar adalah tutup kepala, bukan penutup muka dan yang dimaksud jaib adalah dada. Para wanita itu telah diperintahkan untuk meletakkan kain penutup di atas kepalanya dan melebarkannya sampai menutupi dadanya. ${ }^{3}$

Menurut Muhammad Fauzi Umma bagi kelompok yang memahami ketentuan aurat dalam fiqih sebagai ketentuan final dan menerimanya secara taken for granted aurat laki-laki adalah hanya antara pusar sampai lutut, sedangkan bagi perempuan seluruh tubuhnya. Oleh karena itu, perempuan wajib berjilbab. Batasan aurat dan kewajiban berjilbab bagi perempuan merupakan hasil pemahaman secara tekstual terhadap ayat Al-Qur'a>n dan Sunnah ${ }^{4}$.

Belakangan ini muncul pemikiran Muhammad Shahrur, salah seorang pemikir hukum liberal, dengan analisis yang lebih tajam. Dan menurut Shahrur Q.S 33:59 hanyalah sebagai ayat ta'lim (pendidikan tentang etika) berbusana sebagai muslimah bukan sebagai ayat tashri' yang mewajibkan muslimah untuk berjilbab. ${ }^{5}$

Oleh karena itu menurut Shahrur apa yang kita sebut sekarang dengan istilah"pakaian syari'at" sebenarnya adalah pakaian perempuan arab mukminah dan nasrani pada abad ke tujuh masehi. Batas minimal pakaian perempuan mukminah

\section{7}

${ }^{1}$ Yunahar Ilyas, Tafsir Tematis Cakrawala Al-Qur'an (Yogyakarta: Suara Muh\}ammadiyah, 2003),

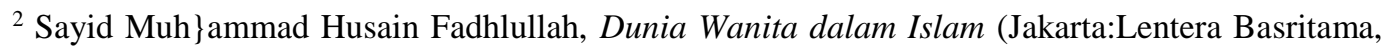
2000), 121

${ }^{3}$ Muh \}ammad Jawad Mughniyah, Fiqih Lima Madzhab:Ja'fari, H\}anafi, Malki, Syafi'i, Hambali, (Jakarta: PT. Lentera Basritama, 1996), 82

${ }^{4}$ Sri Suhandjati Sukri, Pemahaman Islam dan Tantangan Keadilan Jender, (Yogyakarta:Gama Media, 2002), 139

5 Ibid., 141 
dijelaskan pada surat Al-Nur dan berlaku bagi seluruh perempuan mukminat di muka bumi ini, dimana saja, dan kapan saja ${ }^{6}$.

\section{Metodologi penelitian}

1. Jenis penelitian

Jenis penelitian dalam kajian ini adalah penelitian kepustakaan (library research), yaitu penelitian yang obyek utamanya adalah buku-buku atau sumber kepustakaan lain, maksudnya data-data dicari dan ditemukan melalui kajian pustaka dari buku yang relevan dengan pembahasan. ${ }^{7}$

2. Sumber data

Sumber data yang dijadikan bahan-bahan dalam kajian ini merupakan sumber data yang diperoleh dari bahan-bahan pustaka yang dikategorikan sebagai berikut:

a. Sumber data primer

Sumber data primer merupakan bahan utama atau rujukan utama dalam mengadakan suatu penelitian untuk mengungkapkan dan menganalisis penelitian tersebut. Adapun data primer yang penulis gunakan adalah: Prinsip dan Dasar Hermeneutika Hukum Islam Dan Kontemporer ${ }^{8}$, Metodologi Fiqih Islam Kontemporer ${ }^{9}$, pemahaman islam dan tantangan keadilan jender ${ }^{10}$.

b. Sumber data sekunder

Penelitian ini mengunakan pula buku-buku sekunder, untuk membantu menelaah data-data yang dihimpun dan sebagai komparasi dari sumber data primer, antara lain: wawasan Al-Qur'a>n: Tafsir maudhu'i atas pelbagai persoalan umat ${ }^{11}$, menggugat sejarah perempuan: mewujudkan idealism gender sesuai tuntunan Islam $^{12}$, dunia wanita dalam Islam, hak-hak perempuan relasi jender menurut tafsir

6 Muhłammad Shahrur, Prinsip dan Dasar Hermeneutika Hukum Islam Kontemporer, (Yogyakarta: eLSAQ Press, 2007), 265

${ }^{7}$ Hadari Nawawi, Penelitian Terapan (Yogyakarta: Gadjah Mada University Pers, 1994), 23.

${ }^{8}$ Muh ammad Syahrur,Prinsip dan Dasar Hemeneutika Hukum Islam Kontemporer, (Yogyakarta: Elsaqpress, 2007)

${ }^{9}$ Muh \}ammad Syahrur, Metodologi Fiqih Islam Kontemporer, ( Yogyakarta:Elsaqpress, 2008) Media, 2002)

${ }^{10}$ Sri Suhandjati Sukri, Pemahaman Islam dan Tantangan Keadilan Jender, (Yogyakarta:Gama

${ }^{11}$ Muh Jammad Quraish Shihab, Wawasan al-Qur'an:Tafsir Maudhu'i atas Pelbagai Persoalan Umat, (Bandung: Mizan Media Utama, 2001)

12 Nasif, Fatima Umar, Menggugat Sejarah Perempuan:Mewujudkan Gender Sesuai Tuntunan Islam, (Jakarta: Cendekia Sentra Muslim, 2001) 
al-Sya'rawi, muslimah ideal pribadi Islam dalam al-Quran dan Sunnah ${ }^{13}$, tafsir tematis cakrawala al-Qur'a $>n^{14}$.

3. Teknik pengumpulan data

Penelitian ini termasuk penelitian kepustakaan, oleh karena itu teknik yang digunakan dalam pengumpulan data adalah pengumpulan data literatur, yaitu pengumpulan bahan-bahan pustaka yang koheren dengan obyek pembahasan yang dimaksud. ${ }^{15}$

4. Analisis data

Sesuai tujuan penelitian di atas, penelitian ini menggunakan metode berfikir deduktif, dan teori hermeneutika objektif. Metode deduktif dimaksudkan untuk membahas secara deduktif pemikir Shahru>r, sedang hermeneutika teoritis untuk mendeskripsikan pemikiran Shahru>r tentang batas minimal dan maksimal aurat perempuan.

Pengertian hermeneutika: hermeneutika merupakan turunan dari kata kerja Yunani, hermeneneuin yang berhubungan dengan kata benda hermenes dan terkait dengan Dewa Mitologi Yunani Kuno yang bernama Hermes. Hermes merupakan utusan para dewa untuk membawa wahyu Tuhan yang memakai bahasa "langit" kepada manusia yang menggunakan bahasa "dunia".

Hermeneutika berarti suatu ilmu yang mencoba menggambarkan bagaimana sebuah kata atau suatu kejadian pada waktu dan budaya yang lalu dapat dimengerti dan menjadi bermakna secara eksistensial dalam situasi sekarang. Dengan kata lain, hermeneutika merupakan teori pengoperasian pemahaman dalam hubungannya dengan interpretasi terhadap sebuah teks. Objek kajian utamanya adalah pemahaman makna pesan yang terkadang dalam teks dengan variabelnya. Tugas utama adalah mencari dinamika internal yang mengatur struktur kerja suatu teks untuk memproyeksikan diri ke luar dan memungkinkan makna itu muncul ${ }^{16}$

Hermeneutika teoritis: Hermeneutika yang menitik beratkan pada problem “pemahaman”, yakni bagaimana memahami dengan benar sedangkan makna yang

\footnotetext{
${ }^{13}$ Muh $\}$ ammad Ali al-Hasyimi,Muslimah Ideal Pribadi Islami Dalam al-Qur'an dan as-Sunnah, (Yogyakarta: Mitra Pustaka, 2004) 2003),

${ }^{14}$ Yunahar Ilyas, Tafsir Tematis Cakrawala Al-Qur'an (Yogyakarta: Suara Muh\}ammadiyah,

${ }^{15}$ Suharsimi Arikunto, Prosedur Penelitian suatu Pendekatan Praktek (Jakarta: Rineka Cipta, 1990), 24. 2009), 24
} 
menjadi tujuan pencarian dalam hermeneutika ini adalah makna yang dikehendaki oleh penggagas teks. Oleh karena tujuannya memahami secara objektif maksud pengagas maka hermeneutika model ini juga dianggap sebagai hermeneutika romantik yang bertujuan untuk "merekonstruksi makna".

Dalam rangka merekonstruksi makna, Scheleimacher, sebagai pencetus hermeneutika toritis, menawarkan dua pendekatan: pertama pendekatan linguistic yang mengarah pada analisis teks secara langsung, dan kedua, pendekatan psikologis yang mengarah pada unsur psikologis-subjektif sang pengagas sendiri. Dua unsur pendekatan ini dalam hermeneutika toritis dipandang sebagai dua hal yang tidak boleh dipisah, memisah salah satunya akan menyebabkan sebuah pemahaman terhadap pemikiran seseorang menjadi tidak objektif. Sebab, teks berfungsi sebagai media penyampaian gagasan penggagas kepada audiens. Agar pembaca memahami makna yang dikehedaki pengagas teks, hermeneutika teoritis mengansumsikan seorang pembaca harus menyamakan posisi dan pengalamannya dengan pengagas teks. Dia seolah-olah bayangan pengagas teks. Agar mampu menyamakan posisinya dengan penggagas, dia harus mengosongkan dirinya dari sejarah hidup yang membentuk dirinya, dan kemudian memasuki sejarah hidup penggagas dengan cara berempati kepada pengagas. ${ }^{17}$

\section{Pembahasan}

\section{A. Macam-macamTeori Batas Muh\}ammad Shahrur}

Dari sinilah Shahrur kemudan mengenalkan apa yang disebut sebagai "Teori Limitasi“" (Teori Batas). Asumsi dasarnya adalah bahwa Allah SWT di dalam al-Qur'a>n menetapkan konsep hukum maksimum dan minimum (al-Istiqa>mah/ curvature), dan manusia bergerak dari dua batasan tersebut (al-H\}ani>fiyyah/straightness).

Terkait dengan Teori Batas (Teori Limit) yang dikemukannya, Shahru>r menjelaskan enam model teori batas, yaitu:

1. Batas maksimal

2. Batas minimal

3. Batas maksimal dan minimal sekaligus

4. Batas maksimal dan minimal sekaligus tetapi dalam satu titik koordinat

\footnotetext{
${ }^{17}$ Ibid., 26
} 
5. Batas maksimal dengan satu titik yang cenderung mendekati garis lurus tapi tidak ada persentuhan

6. Batas maksimal positif dan tidak boleh dilampaui, batas minimum negative boleh dilampaui. $^{18}$

Disini penulis juga memberikan contoh terhadap keenam teori di atas beserta batasan-batasan penetapan hukum dan ibadah ritual:

1. Posisi batas minimal (ha>lah al-had al-adna>>)

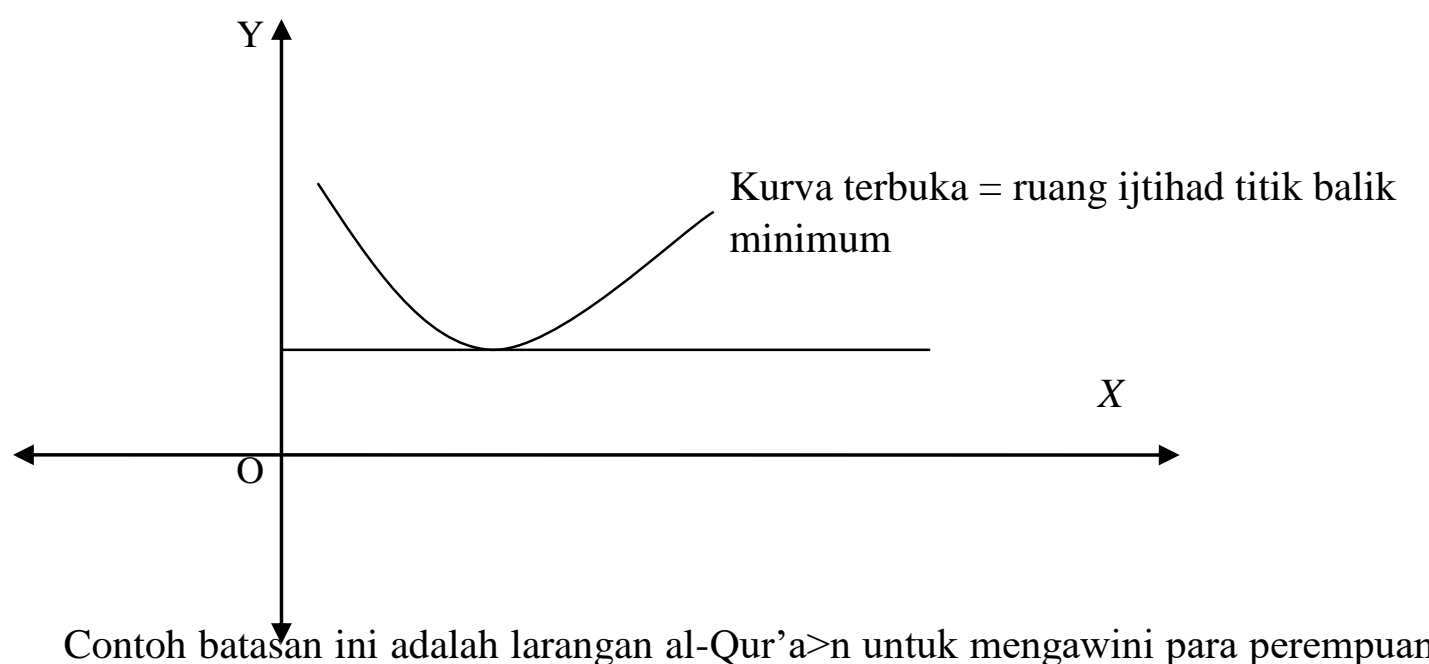
yang disebut dalam (Q.S. al-Nisa>': 23):

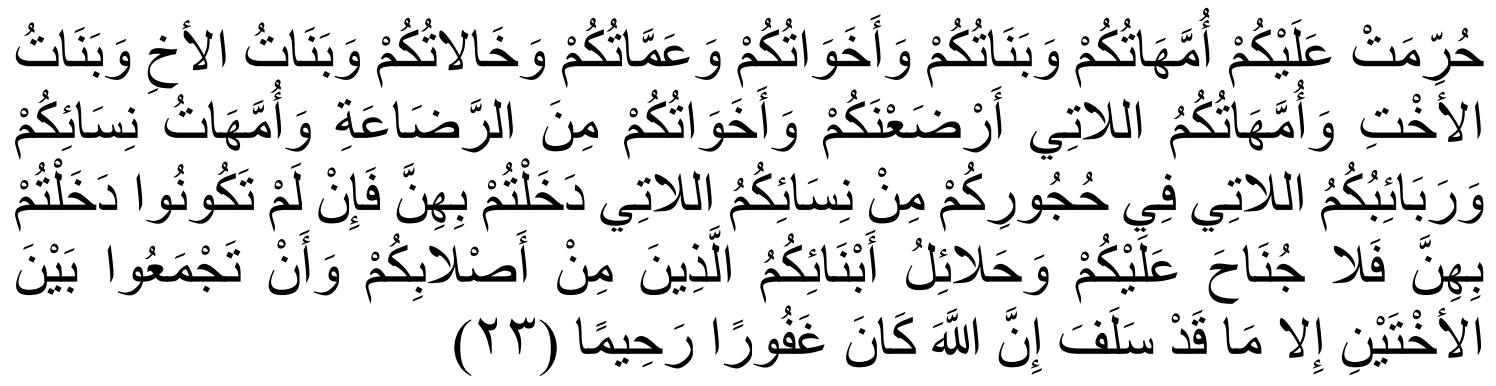

Diharamkan atas kamu (mengawini) ibu-ibumu; anak-anakmu yang perempuan; saudara-saudaramu yang perempuan, saudara-saudara bapakmu yang perempuan; saudara-saudara ibumu yang perempuan; anak-anak perempuan dari saudara-saudaramu yang laki-laki; anak-anak perempuan dari saudarasaudaramu yang perempuan; ibu-ibumu yang menyusui kamu; saudara perempuan sepersusuan; ibu-ibu isterimu (mertua); anak-anak isterimu yang dalam pemeliharaanmu dari isteri yang telah kamu campuri, tetapi jika kamu belum campur dengan isterimu itu (dan sudah kamu ceraikan), Maka tidak berdosa kamu mengawininya; (dan diharamkan bagimu) isteri-isteri anak kandungmu (menantu); dan menghimpunkan (dalam perkawinan) dua perempuan yang bersaudara, kecuali yang telah terjadi pada masa lampau; Sesungguhnya Allah Maha Pengampun lagi Maha Penyayang.

${ }^{18}$ Ridwan, Muhłammad Shahrur: Limitasi Hukum Pidana Islam (Semarang: Walisongo Press, 
Menikah dengan anggota keluarga yang termasuk ketegori hubungan-hubungan darah ini dilarang, yang diperbolehkan adalah menikah dengan kerabat lain di luar anggota ikatan darah yang disebutkan dalam ayat di atas. ${ }^{19}$ Dalam kondisi apaun, tidak seorangpun diperbolehkan melanggar batasan ini meski didasarkan pada ijtihad. Ijtihad hanya diperbolehkan pada usaha memperluas pihak yang diharamkan.

2. Posisi batas maksimal (ha>lah al-had al-a 'la>).

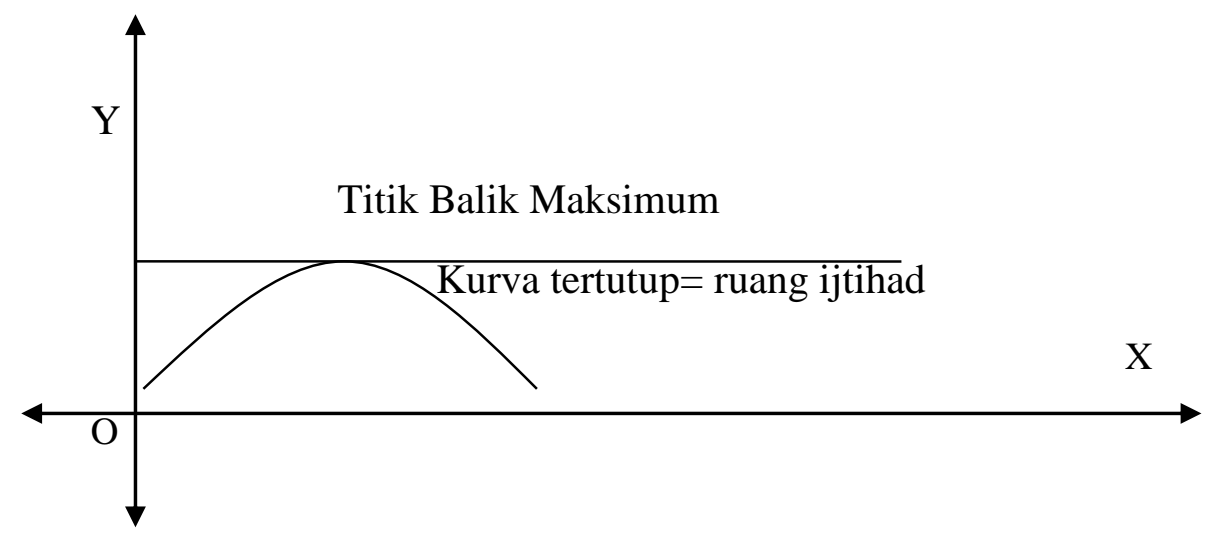

Contoh posisi batas maksimal ini di dapat ditemukan dalam (Q.S. al-Maidah: 38)

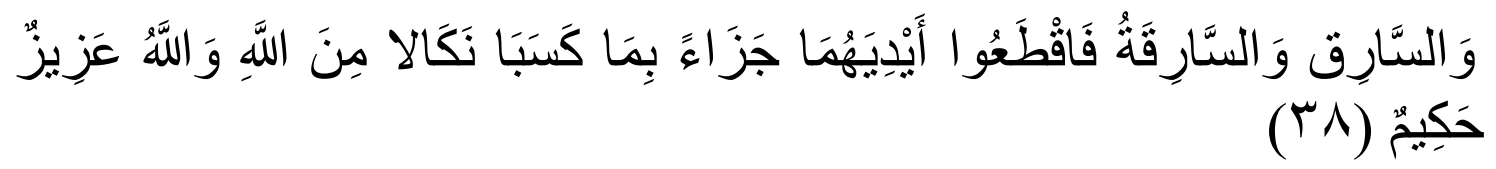

laki-laki yang mencuri dan perempuan yang mencuri, potonglah tangan keduanya (sebagai) pembalasan bagi apa yang mereka kerjakan dan sebagai siksaan dari Allah. dan Allah Maha Perkasa lagi Maha Bijaksana.

" Pencuri, baik laki-laki maupun perempuan, maka potonglah tangan-tangan mereka". Di sini hukuman yang ditentukan mewakili batasan maksimum yang tidak boleh dilampaui. Dalam kasus ini hukuman bisa dikurangi, berdasarkan kondisi-kondisi obyektif yang berlaku dalam suatu masyarakat tertentu. ${ }^{20}$ Dalam hal ini tampak bahwa ijtihad membuka peluang yang sangat luas bagi para penentu hukum yang sangat sesuai dengan sifat kelenturan islam dalam masalah ijtihad. Para Mujtahid berkewajiban untuk menentukan kriteria pencurian yang harus menerima hukuman maksimal, yaitu potong tangan, berdasarkan latar belakang obyektif pada ruang dan waktu mereka hidup. ${ }^{21}$

19 Muh \}ammad Syahrur, Prinsip dan Dasar Hermeneutika Hukum Islam Kontemporer , (Yogyakarta: eLSAQ Press, 2007), 7

${ }^{20}$ Ibid., 7

${ }^{21}$ Ibid., 35 
3. Posisi batas maksimal dan minimal bersamaan (ha>lah al-had ala'la $>$ wa al-adna> ma'an)

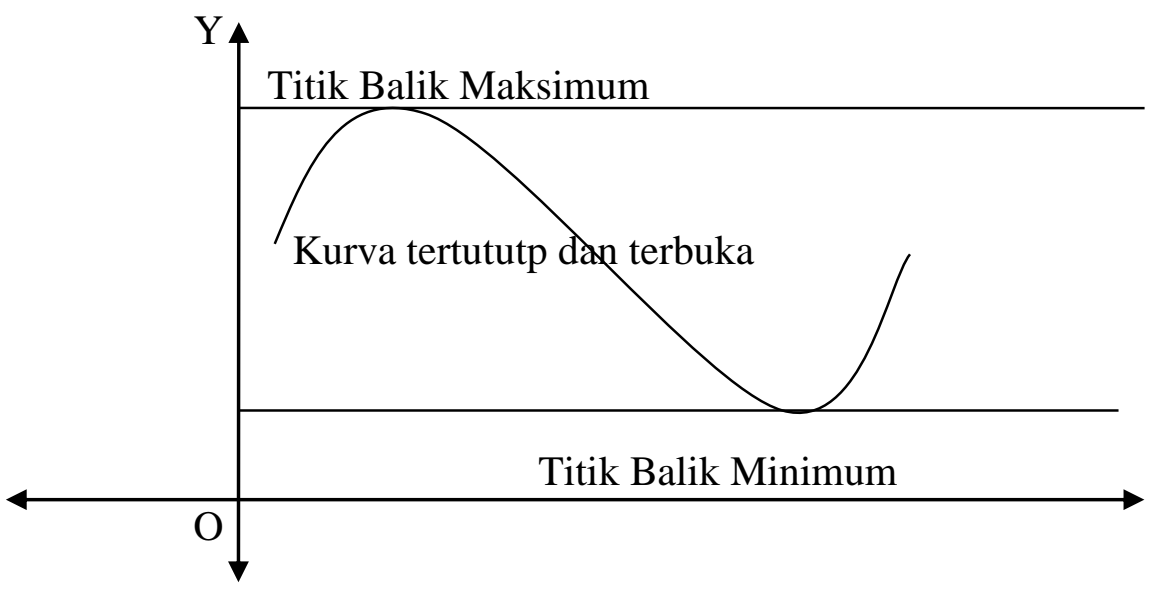

Dan sekaligus. Contoh dari tipe ini disebutkan dalam al-Qur'a>n (Q.S. alNisa $>$ "':11)

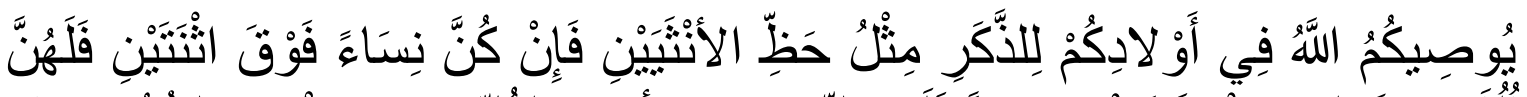

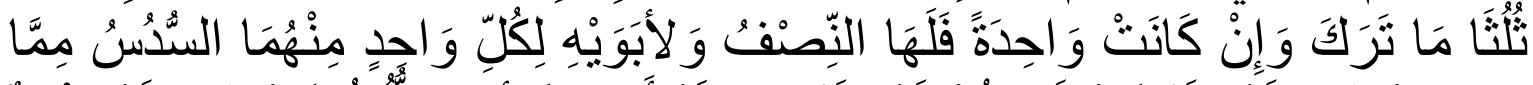

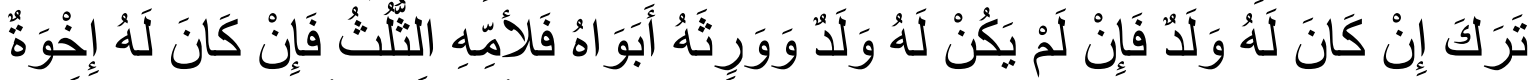

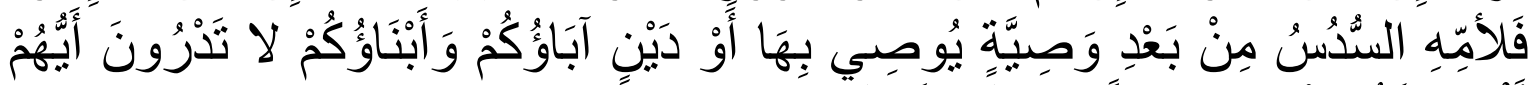

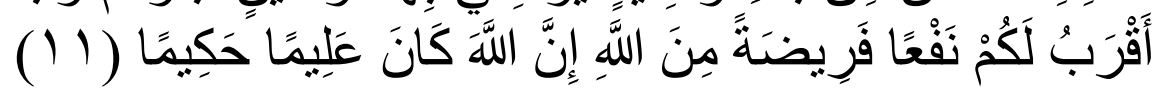

11. Allah mensyari'atkan bagimu tentang (pembagian pusaka untuk) anak-anakmu. Yaitu : bahagian seorang anak lelaki sama dengan bagahian dua orang anak perempuan[272]; dan jika anak itu semuanya perempuan lebih dari dua[273], Maka bagi mereka dua pertiga dari harta yang ditinggalkan; jika anak perempuan itu seorang saja, Maka ia memperoleh separo harta. dan untuk dua orang ibu-bapa, bagi masing-masingnya seperenam dari harta yang ditinggalkan, jika yang meninggal itu mempunyai anak; jika orang yang meninggal tidak mempunyai anak dan ia diwarisi oleh ibu-bapanya (saja), Maka ibunya mendapat sepertiga; jika yang meninggal itu mempunyai beberapa saudara, Maka ibunya mendapat seperenam. (Pembagian-pembagian tersebut di atas) sesudah dipenuhi wasiat yang ia buat atau (dan) sesudah dibayar hutangnya. (Tentang) orang tuamu dan anak-anakmu, kamu tidak mengetahui siapa di antara mereka yang lebih dekat (banyak) manfaatnya bagimu. ini adalah ketetapan dari Allah. Sesungguhnya Allah Maha mengetahui lagi Maha Bijaksana.

4. Posisi batas lurus ( $h a>$ lah al-mustaqi $>m$ ) 
Nilai Y selalu tetap untuk nilai X (hukum tidak berubah meski zaman terus bertambah)

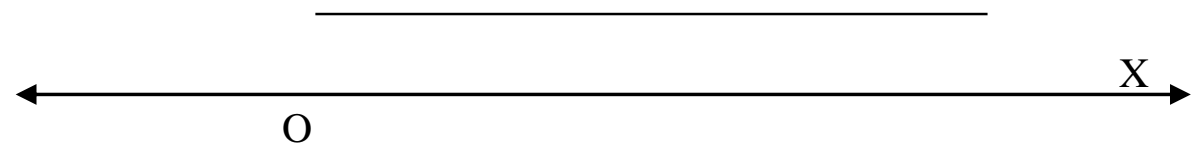

Perpaduan Antara Batasan-Batasan Maksimum dan Minimum. Yang menarik disini adalah bahwa dari seluruh kandungan al-Qur'a $>n$ dan Sunnah hanya ada satu ayat dalam tipe ini, yakni (Q.S. al-Nu>r: 2).

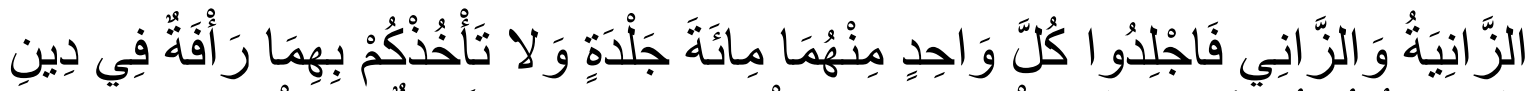

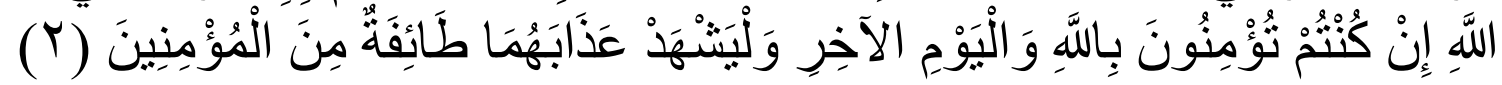

Perempuan yang berzina dan laki-laki yang berzina, Maka deralah tiap-tiap seorang dari keduanya seratus dali dera, dan janganlah belas kasihan kepada keduanya mencegah kamu untuk (menjalankan) agama Allah, jika kamu beriman kepada Allah, dan hari akhirat, dan hendaklah (pelaksanaan) hukuman mereka disaksikan oleh sekumpulan orang-orang yang beriman.

Disini batasan maksimum dan minimum berpadu pada satu bentuk hukuman, yakni berupa seratus deraan. Tuhan menekankan bahwa pezina seharusnya tidak dikasihani dengan mengurangi hukuman-hukumanan yang seharusnya ditimpakan. Hukuman bagi pezina adalah tidak boleh kurang dari seratus deraan.

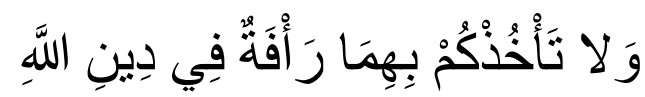

Dalam redaksi ayat diatas secara jelas terdapat peringatan agar tidak memperingan hukuman. Karena hukuman tersebut juga berposisi sebagai batas minimal.

5. Posisi batas maksimal cenderung mendekat tanpa persentuhan (ha>lah al-had-a'la likha>t al-muqari>b du>nal mamas bi alha>d al-adna> abadan $)^{22}$

Titik final akan berhimpit dengan sumbu $\mathrm{Y}$ di daerah tak terhipgga

Hubungan lawan jenis bermula dari saling memandang bersentuhan dan seterusnya hingga terjadi coitus (li taqarubu al-zina)

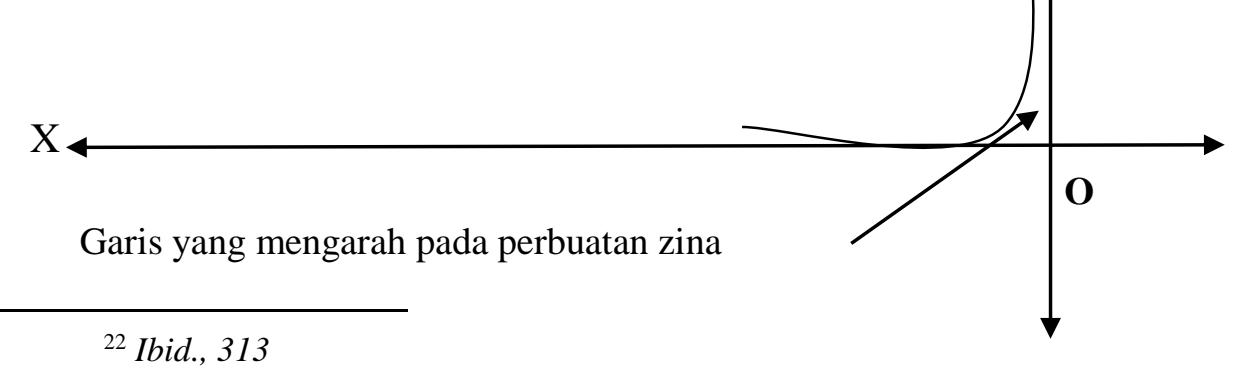


Posisi ini diterapkan dalam batasan hubungan fisik antara laki-laki dan perempuan. Hubungan fisik terjadi antara manusia yang berbeda jenis, bermula dari batasannya yang paling rendah, berupa tanpa persentuhan sama sekali antara keduanya dan berakhir pada batasan paling tinggi,berupa tindakan yang menjurus hubungan kelamin yang disebut sebagai zina. ${ }^{23}$ Tipe ini berupa batasan hukum Tuhan adalah garis lengkung (para bola) yang bergerak diantara batas maksimal dan minimal tanpa ada persentuhan dengan keduanya. Berawal dari satu titik di atas garis batas minimal, dimana dua jenis kelamin tidak bersentuhan, garis lengkung terus naik mengarah pada batas maksimal dimana mereka hampir melakukan tahap perzinaan (hubungan seksual) tapi tahap ini belum sampai terjadi. Dari tipe batas Tuhan ini kita dapat menyimpulkan bahwa dalam masyarakat yang memisahkan secara tegas ruang antara laki-laki dan perempuan, kasus ini berada di luar batas minimal. Dalam masyarakat dimana perzinahan sudah umum terjadi, kasus ini menyentuh batas maksimal. Ketika laki-laki dan perempuan bekerja bersama di pabrik atau di kantor atau belajar bersama di Unifersitas, maka hal demikian dapat diterima secara islam. Hal itu juga tergantung pada perkembangan sosial pada masyarakat itu sendiri dan islam tidak perlu dipertentangkan dengan hal tersebut. ${ }^{24}$

6. Posisi batas maksimal positif dan batas minimal negatif (ha>lah alhad al-a'la> mujaban wa al-adna> saliban)

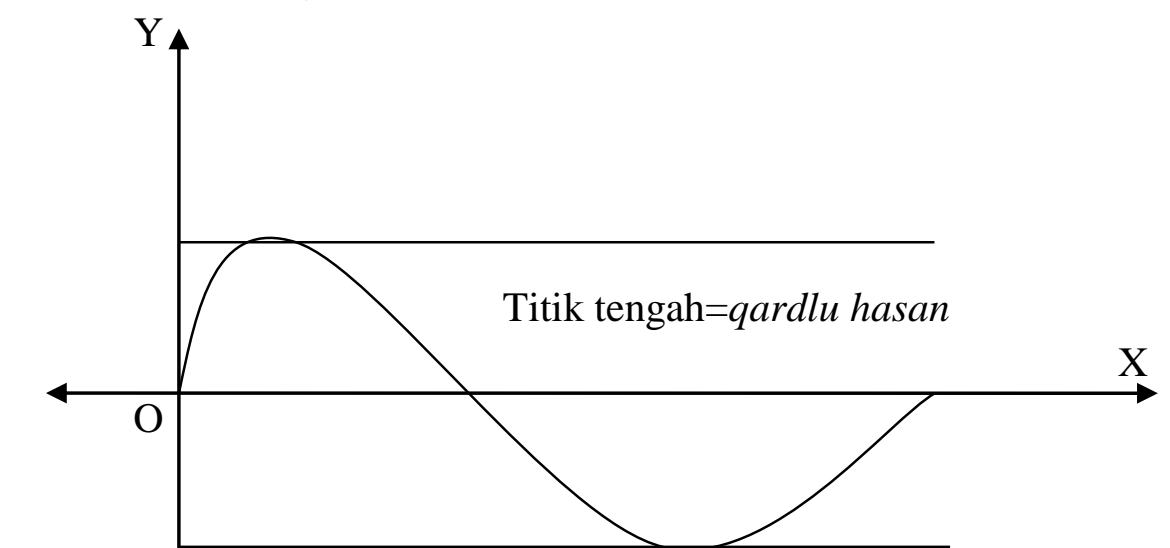

\footnotetext{
Titik balik minimum di daerah negatif $=$ zakat $2,5 \%$

Kasu hukum yang menggambarkan ini adalah transaksi uang. Batas tertinggi membayarkan zakat. Ketika batasan-batasan ini berada dalam posisi positif dan negatif, maka ada sebuah tingkatan yang berada tepat diantaranya yang nilainya sama dengan nol. Contoh dari tingkatan tengah ini adalah hutang bebas bunga. Dengan demikian, ada
} 
tiga kategori besar untuk transaksi keuangan: (1) Pembayaran pajak; (2) Pemberian hutang bebas bunga; dan (3) Pemberian hutang dengan bunga.

Dalam kajian tentang tipe keenam ini, Shahru>r memperkenalkan kajian bunga secara baik dan rinci. Shahru>r menjelaskan bahwa arti riba dalam bahasa arab adalah "pertumbuhan dan perkembangan" dari kekayaan. Syahur berpendapat bahwa larangan atas bunga adalah bukan ketentuan dalam islam. Dalam mendukung pendapatnya ini dia menyebut bahwa Umar Bin Khatab dilaporkan menginginkan nabi agar menjelaskan secara eksplisit syarat-syarat status hukum bunga. Berdasarkan Q.S al-Taubat: 60," zakat adalah hanya untuk mereka yang miskin dan yang membutuhkan”, Shahru>r menafsirkan bahwa orang miskin dan orang yang membutuhkan dalam masyarakatmasyarakat modern adalah mereka yang tidak mampu membayar hutang. ${ }^{25}$

Dari bebrapa teori yang telah disebutkan pada tulisan diatas, sesuai dengan kajian yang akan saya teliti, akan banyak mengulas tentang teori yang ketiga yaitu batas minimal dan maksimal secara bersamaan. Untuk lebih memudahkan dalam memahami kajian ini akan dijelaskan beberapa hal yang berkaitan dengan tema-tema yang akan dibahas.

\section{B. Definisi Aurat (As-Saw'ah)}

Aurat berasal dari kata 'aurah yang oleh sementara ulama dinyatakan terambil dari kata 'awara yang berarti hilang perasaan, jika kata tersebut dikaitkan dengan mata, maka ia berarti hilang potensi pandangannya (buta) tetapi biasanya ia hanya gunakan bagi yang buta sebelah. Sedangkan bila kata itu digandengkan dengan kalimat maka ia berarti ucapan yang buruk dan mengundang amarah pendengarnya. Dari makna-makna diatas kata'aurat dipahami dalam arti sesuatu yang buruk, atau sesuatu yang hendaknya diawasi karena kosong,rawan, dan dapat menimbulkan bahaya dan rasa malu. ${ }^{26}$

Kata $a s$-saw'ah juga memiliki arti denotative maupun konotatif. Secara denotative kata ini berarti keburukan (al-Qubh), seperti disebutkan dalam Hadist: saw'au walu>dun khayrun min hasna 'aqi>min (perempuan buruk rupa namun subur lebih baik dari pada perempuan cantik atau mandul). Kata Ini juga berarati al-Bara $>s$ (bintik-bintik putih pada kulit), seperti disebut dalam firman Allah: Q.S. Taha :22. Pendapat ini dipegang oleh $a l-J a>h i z$ yang mengutip dari az-Zamakhshari>. Secara konotatif kata as-Saw'ah berarti aurat, yaitu bagian tubuh yang tidak boleh dibuka untuk diperlihatkan.

25 Muh\}ammad Shahrur, Prinsı 44 uur Dasar Hermeneutika Hukum Islam Kontemporer (Yogyakarta:eLSAQ Press, 2007), 10

${ }^{26}$ Quraish Shihahb, Jilbab,Pakaian Wanita Muslima, (Jakarta: lentera Hati, 2004),43 
Berdasarkan hal ini muncul pendapat bahwa kata tersebut adalah kiasan (Kina>yah) tentang alat kelamin laki-laki dan perempuan yang jika diperlihatkan akan menganggu pihak lain selain itu kata as-Saw'ah juga berarti aib (Fadihah) dan bangkai (Jifah), seperti dalam firman Allah al-Maidah: $31^{27}$.

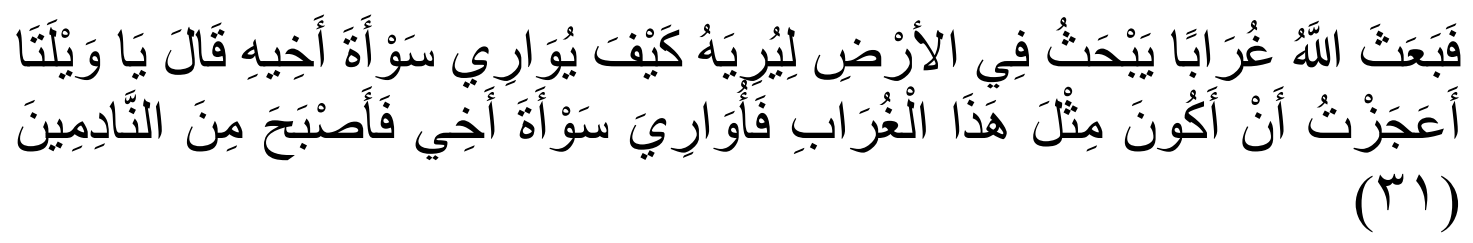

Kemudian Allah menyuruh seekor burung gagak menggali-gali di bumi untuk memperlihatkan kepadanya (Qabil) bagaimana seharusnya menguburkan mayat saudaranya. berkata Qabil: "Aduhai celaka Aku, mengapa aku tidak mampu berbuat seperti burung gagak ini, lalu aku dapat menguburkan mayat saudaraku ini?" karena itu jadilah Dia seorang diantara orang-orang yang menyesal.

Kata 'aurat berasal dari konsep tentang rasa malu, yaitu tidak adanya kerelaan manusia untuk memperlihatkan sesuatu, baik yang ada pada dirinya maupun perilakunya. Tingkatan rasa malu bersifat relatife, tidak mutlak, dan mengikuti kebiasaan setempat. Ketentuan tentang batasan daerah-daerah intim pada tubuh (alJuyu $>$ b) bersifat tetap, tetapi yang terkait dengan batasan 'aurat dapat berubah-ubah sesuai dengan perkembangan zaman dan tempat. ${ }^{28}$

\section{Aurat Menurut Para Ulama'}

Ulama yang menafsiri tentang aurat itu yang pertama yaitu Ahmad Must $\} a>$ fa> al-Mara>ghi> , Tafsir al-Maraghi merupakan salah satu Tafsir Alquran. al-Maraghi memadukan metode Aqli dan Naqli dalam menyelesaikan penafsiran ini. al-Mara>ghi> menafsiri tentang batasan aurat perempuan yaitu supaya menutup seluruh tubuh wajah dari atas kepala dengan jilbab, dan boleh menampakkan satu mata saja. Penafsiran ini diambil dari surat al-Ahzab (59). Yang didalamnya dijelaskan bahwa nabi memerintahkan wanita-wanita mu'minat dan muslimat, khususnya para istri dan anakanak perempuan beliau, supaya mengulurkan pada tubuh mereka jilbab-jilbab, apabila mereka keluar dari rumah, dan juga untuk membedakan dengan budak ${ }^{29}$.

${ }^{27}$ Muh \}ammad Shahrur, Metodologi Fiqih Islam Kontemporer (Yogyakarta:eLSAQ Press :2008),486

28 Muh ammad Shahrur, Prinsip dan Dasar Hermeneutika Hukum Islam Kontemporer, (Yogyakarta: eLSAQ Press, 2007), 256

${ }^{29}$ Ahmad Mustafa al-Maraghi, Tafsir al-Maraghi, (Semarang: Toha Putra Semarang,1992),63 
Ulama' madzhab Ja'fari>, H\}anafi>, Maliki>, Shafi'i>, dan Hambali>) sepakat bahwa aurat perempuan adalah semua badan , kecuali muka dan telapak tangannya, berdasarkan firman Allah dalam surat al-Nu>r ayat 31:

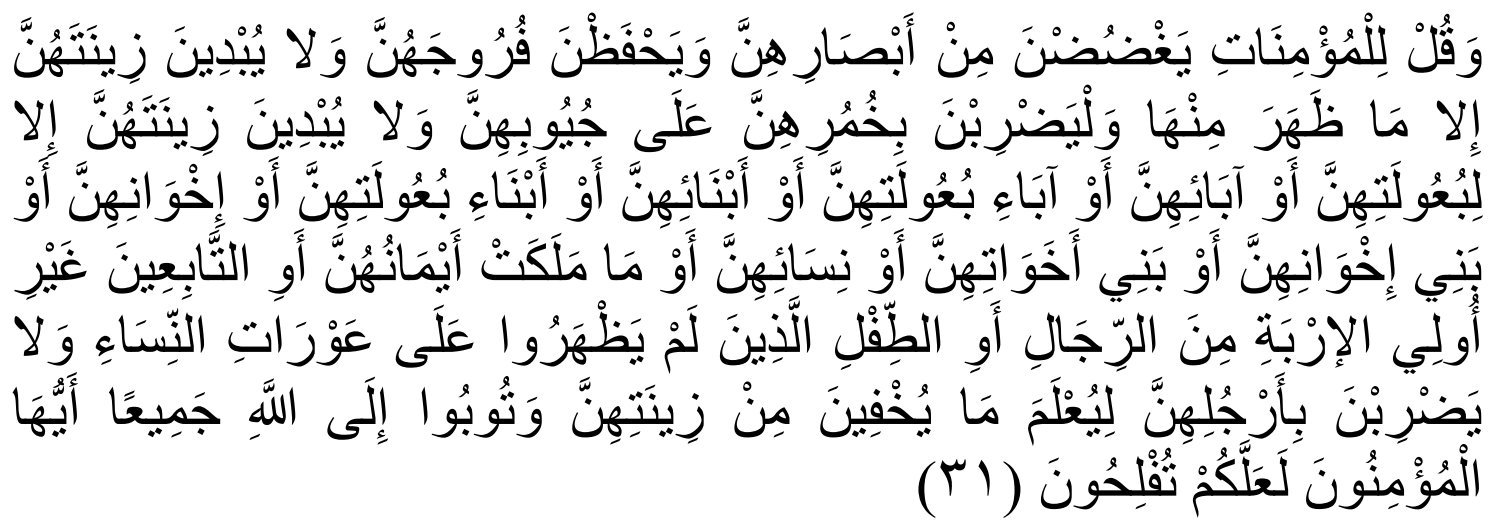

Katakanlah kepada wanita yang beriman: "Hendaklah mereka menahan pandangannya, dan kemaluannya, dan janganlah mereka Menampakkan perhiasannya, kecuali yang (biasa) nampak dari padanya. dan hendaklah mereka menutupkan kain kudung kedadanya, dan janganlah Menampakkan perhiasannya kecuali kepada suami mereka, atau ayah mereka, atau ayah suami mereka, atau putera-putera mereka, atau putera-putera suami mereka, atau saudara-saudara laki-laki mereka, atau putera-putera saudara lelaki mereka, atau putera-putera saudara perempuan mereka, atau wanita-wanita Islam, atau budak- budak yang mereka miliki, atau pelayan-pelayan laki-laki yang tidak mempunyai keinginan (terhadap wanita) atau anak-anak yang belum mengerti tentang aurat wanita. dan janganlah mereka memukulkan kakinyua agar diketahui perhiasan yang mereka sembunyikan. dan bertaubatlah kamu sekalian kepada Allah, Hai orang-orang yang beriman supaya kamu beruntung.

Yang dimaksud dengan perhiasan yang nampak itu adalah muka dan telapak tangan. Sedangkan yang dimaksud dengan khima $>r$ adalah tutup kepala, bukan penutup muka dan yang dimaksud dengan jaib adalah dada. Para wanita itu telah diperintahkan untuk meletakkan kain penutup kepala dan melebarkannya sampai menutupi dadanya. Kalau yang dimaksud dalam surat al-Ahzab ayat 1, seperti:

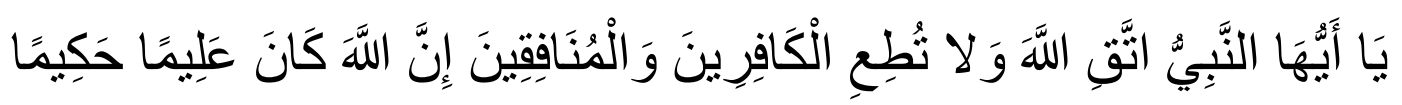

Hai Nabi, bertakwalah kepada Allah dan janganlah kamu menuruti (keinginan) orang-orang kafir dan orang-orang munafik. Sesungguhnya Allah adalah Maha mengetahui lagi Maha Bijaksana

Maka yang dimaksud itu adalah bukan penutup wajah, tetapi ia hanya baju dan

kain. $^{30}$

${ }^{30}$ Muh \}ammad Jawad Mughniyah, Fiqih Lima Madzhab:Ja'fari, H\}anafi, Malki, Syafi'i, Hambali, (Jakarta: Pt.Lentera Basritama, 1996), 82 
Mengenai batasan aurat, menurut Nashruddin Baidan bahwa dalam al-Quran sudah dijelaskan dalam surat al-Nu>r dan al-Ahzab. Kalau dalam surat al-Ahzab itu tidak secara mutlak memerintahkan kaum wanita memakai jilbab untuk menutupi aurat, tapi dalam surat al-Nu>r secara tegas meminta kaun wanita agar menjaga kehormatan dan menutup aurat mereka dari orang-orang yang tidak boleh melihatnya. Dan pada hakikatnya kedua surat itu bermaksud memelihara kesucian dan kehormatan kaum perempuan, sehingga mereka dapat hidup dalam suasana damai dan tentram sepanjang hayatnya.

Nashruddin Baidan ini juga mempunyai pendapat yang berbeda, bahwa yang diperlukan oleh al-Qur'a>n ialah menutup aurat, bukan memakai jilbab. Dengan kata lain, apabila aurat sudah tertutup, maka model pakaian tidak menjadi problema: apakah model jilbab sebagaimana bangsa arab atau model baju kurung dan sebagainya. ${ }^{31}$

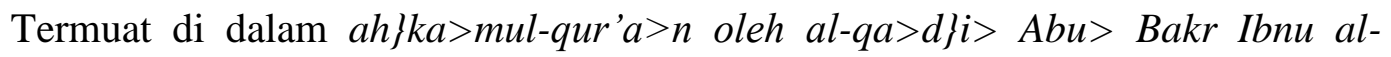
'A $>r a>b i>$, firman-Nya, "walyadhribna bi khumu>rihinna 'ala juyu>bihinn." Jaib adalah kerah baju dan khimar adalah penutup kepala. Al-Bukha>ri> meriwayatkan dari 'Aisyah: bahwa dia berkata "semoga Allah mengasihi wanita-wanita muhajir yang pertama. Ketika diturunkan, 'dan hendaklah mereka menutupkan kain kerudung mereka ke dada mereka' mereka membelah kain selendang mereka”. Dan dalam satu riwayat, termuat juga di dalamnya, "mereka membelah kain mereka", lalu berkerudung dengannya, seakan-akan siapa yang mempunyai selendang, maka dia membelah selendangnya, dan siapa yang mempunyai kain, maka dia membelah kainnya. ini menunjukkan bahwa leher dan dada ditutpi dengan apa yang ada padanya. Yang demikian dijelaskan oleh Hadis Aisyah,"'adalah Rasullullah Saw. Setelah selesai shalat subuh, lalu mereka kembali dengan menutupkan selendang mereka, sehingga ${ }^{32}$ mereka tidak dikenali karena gelap dini hari”.

Quraish Shihab berpendapat bahwa dalam al-Qur'a $>n$ tidak ada yang menjelaskan batasan aurat. Pendapatnya ini diambil dari kesimpulan dari beberapa ulama', seperti Muh \}ammad T\}a>hir Bin Ashu>r seorang ulama besar dari Tunis. yang diakui otoritasnya dalam bidang ilmu agama menulis dalam Maqa $>$ s\}id al Shari> 'ah sebagai berikut:

${ }^{31}$ Nashruddin Baidan, Tafsir Bi Al-Ra'yi Upaya Penggalian Konsep Wanita Dalam Al-Qur'an, (Yogyakarta:Pustaka Pelajar, 1999), 123

${ }^{32}$ Abu Syuqqah, Busana dan Perhiasan Wanita Menurut Al-Qur'an Dan Hadis, (Bandung: AlBayan,1995),59 


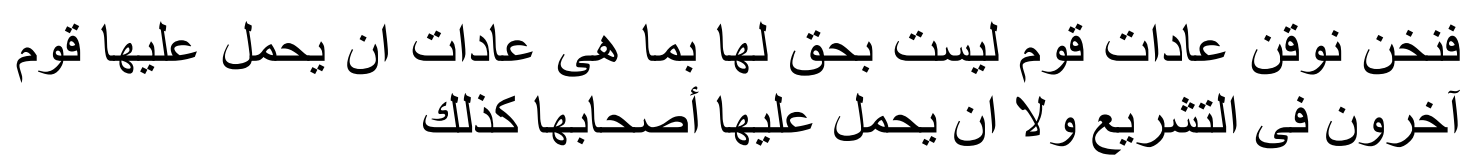

Kami percaya bahwa adat kebiasaan satu kaum tidak boleh dalam kedudukannya sebagai adat untuk dapat dipaksakan terhadap kaum lain atas nama agama, bahkan tidak dapat dipaksakan terhadap kaum itu.

Kemudian Bin Ashu>r, dia memberikan bebearpa contoh dari al-Qur'a $>n$ dan Sunnah nabi. Contoh yang diangkatnya dari al-Qur'a $>$ n adalah surat al-Ahzab (33):59, yang memerintahkan kaum mukminah agar menjulurkan jilbabya. Tulisannya:

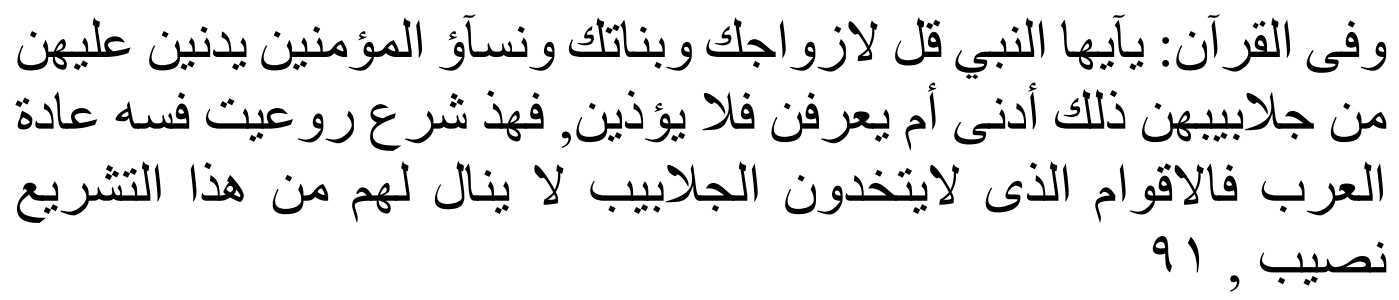

Di dalam al-Qur'a>n dinyatakan, wahai nabi, katakana kepada istri-istrimu, anakanak perempuanmu dan wanita mukmin, hendaklah mereka mengulurkan jilbabnya ke seluruh tubuh mereka, yang demikian itu supaya mereka lebih mudah dikenal sehingga tidak diganggu. Ini adalah ajaran yang mempertimbangkan adat oragorang arab, sehingga bangsa-bangsa lain yang tidak menggunakan jilbab, tidak memperoleh bagian (tidak berlaku bagi mereka) dalam ketentuan ini.

Dalam kitab tafsirnya ia menulis bahwa:

Cara memakai jilbab berbeda-beda sesuai dengan perbedaan keadaan wanita dan adat mereka. Tetapi tujuan perintah ini adalah seperti bunyi ayat itu yakni "agar mereka dapat dikenal (sebagai wanita muslim yang baik) sehingga tidak diganggu”. Kemudian muncul pertanyaan, Tetapi bagaimana dengan ayat-ayat ini, yang menggunakan redaksi perintah? Dan Quraish Shihab menjawabnya, Jawaban yang sering terdengar dalam diskusi adalah: bukankah tidak semua perintah yang tercantum dalam al-Qur'a $>$ n merupakan perintah wajib? Pernyataan itu, memang benar. Perintah menulis hutangpiutang (QS al-Baqarah (2): 282) adalah salah satu contohnya.

Kemudian ada pertanyaan lagi, Tetapi bagaimana dengan hadis-hadis yang demikian banyak? Quraish Shihab pun menjawab, jawabannya pun sama. Bukankah seperti yang dikemukakan oleh Bin Asyur di atas bahwa ada hadits-hadits nabi yang merupakan perintah dalam arti "sebaiknya" bukan seharusnya.

Dan disini Qurais Shihab menyimpulkan dari beberapa pernyataan dari ulama tersebut, kita tidak boleh berkata bahwa wajib menutup seluruh badannya kecuali wajah dan telapak tangannya, menjalankan bunyi teks ayat itu, bahkan mungkin lebih. Namun 
dalam saat yang sama kita tidak wajar menyatakan terhadap mereka yang tidak memakai kerudung, atau menampakkan tangannya bahwa mereka "secara pasti telah melanggar petunjuk agama". Oleh karena itu timbul pertanyaan bukankah al-Quran tidak menyebut batas aurat? Dan ini menjadikan Para ulama pun ketika membahasnya berbeda pendapat.

Qurais Shihab pun dengan bijak menyimpulakan adanya perbedaan pendapat diantara ulama dengan pemikirannya, "bahwa kehati-hatian amat dibutuhkan, karena pakaian lahir dan menyiksa pemakainya sendiri apabila tidak sesuai dengan bentuk badan si pemakai. Demiakan pun pakaian batin. Apabila tidak sesuai dengan jati diri manusia, sebagai hamba Allah, yang paling mengetahui ukuran dan patron terbaik buat manusia" 33 .

Dalam bidang fiqih, Ahli Fiqih membolehkan budak perempuan mengenakan pakaian tertentu. Hal ini kami temukan pada pendapat 'Abd al-Rahman al-Jaziri tentang pakaian perempuan budak dalam shalat, ia berkata:" syarat kedua dalam shalat adalah menutup aurat”. Terdapat perbedaan batasan aurat antara laki-laki, perempuan merdeka dan perempuan budak. Batas aurat laki-laki menurut Maliki> adalah dari pusar sampai lutut. Lutut disepakati sebagai batas aurat, sedangkan pusar terdapat perbedaan pendapat.aurat perempuan budak sama dengan aurat laki-laki merdeka ditambah seluruh bagian perut dan punggung. Aurat perempuan merdeka adalah badannya hingga rambutnya yang terurai disamping kedua telinganya. Hal ini berdasarkan hadis nabi:"perempuan adalah aurat, kecuali kedua telapak tangan dan punggung kedua kaki". Madzhab Sha $>$ fi' $i>$ juga memiliki pendapat yang sama meski dengan sedikit perbedaan. Madzhab Hambali $>$ memiliki pendapat yang sama dengan Sha $>$ fi' $i>y a h$. Hanya saja hambali mengecualikan wajah untuk aurat perempuan merdeka, sedangkan bagian tubuh lainnya aurat. ${ }^{34}$

Kemudian $\mathrm{Abu}>\mathrm{H}$ \}ani>fah juga berpendapat sebagaimana dikutip oleh Syaikh Muh\}ammad 'Ali> Al-Says,

"telapak kaki wanita tidak termasuk aurat, khususnya bagi wanita miskin di pedesaan yang dalam mencari penghidupan mereka terpaksa bekerja keras tanpa menutupi kaki. Jika mereka harus menutupi kaki,niscaya hal ini akan menyulitkan dan membuat susah lagi daripada menutup bagian tangan. Malah abu yusuf (murid Abu> H\}ani>fah) lebih longgar lagi menurutnya kedua tangan wanita bukan aurat, karena itu tidak perlu ditutupi”

\footnotetext{
${ }^{33}$ Muh ammad Quraish Shihab, Wawasan Al-Quran Tafsir Maudhu'i Atas Pelbagai Permasalahan Umat, (Bandung:Mizan Media Utama, 2001), 180

${ }^{34}$ Muh\}ammad Shahrur, Metodologi Fiqih Islam Kontemporer, (Yogyakarta: eLSAQ Press, 2008 ), 507
} 
Pendapat ini pada dasarnya merujuk kepada ucapan Nabi SAW berkenaan dengan kasus Asma' putri Abu Bakar, suatu hari Nabi berkata kepadanya:

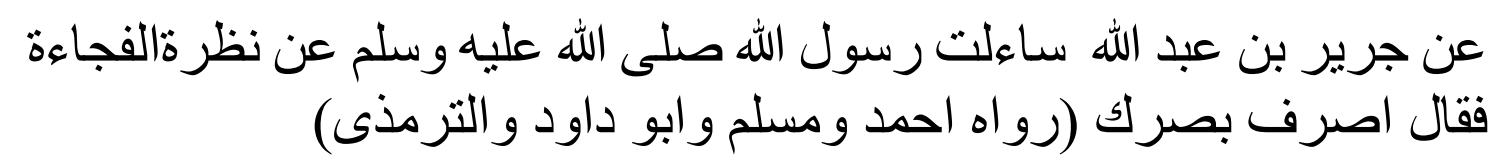

“Hai Asma'! sesungguhnya apabila wanita telah mencapai umur haid, maka tidak patut lagi terlihat darinya selain ini dan ini. Lalu Nabi menunjuk kepada wajah dan telapak tangannya." (H.R Abu Daud dari Aisyah).

Dari hadits di atas dapat memperjelas maksud dari ayat

الا ما ظطر منها itu sehingga dapat dipahami bahwa yang tidak wajib ditutupi dari anggota tubuh wanita itu ialah muka dan kedua telapak tangannya. ${ }^{35}$

\section{Aurat Menurut Muh\}ammad Shahru>r}

Menurut Qurais Shihab, Dalam konteks pakaian, Muh\}ammad Shahru>r menjelaskan bahwa "pakaian yang tertutup yang kini dinamai $h\} i j a>b$ (jilbab) bukanlah kewajiban agama tetapi ia adalah suatu bentuk pakaian yang dituntut oleh kehidupan bermasyarakat dan lingkungan serta dapat berubah dengan perubahan masyarakat. Orang-orang arab sebelum kedatangan islam, juga pada masa kenabian Nabi Muh\}ammad SAW. Dan sesudahnya membedakan antara pakaian wanita merdeka dan hamba sahaya. Pakaian wanita merdeka seperti pakaian Khadi>jah r.a yang disunting oleh Nabi Muh \}ammad SAW adalah penutup kepala yang menampik sengatan panas dan menghimpun rambut sehingga tidak berantakan, serta pakaian panjang yang menutupi bagian bawah badan. Ini karena waktu itu belum lagi dikenal adanya pakaian dalam. Pakaian wanita merdeka waktu itu ketika itu longgar sehingga menjadikan mereka memiliki kebebasan bergerak dalam segala aktifitas mereka, baik di dalam maupun di luar rumah. Pakaian itu tidak memiliki bagian-bagian terbuka kecuali satu, yaitu tempat untuk memasukkan kepala, sehingga bila wanita-wanita itu berpakaian, buah dada mereka dapat terlihat khususnya bila mereka tunduk. Bagian inilah yang diperintahkan oleh surat al-Nu>r (31): 24 untuk ditutupi dengan penutup kepala. Pakaian hamba sahaya wanita berbeda sama sekali dengan pakaian tersebut". ${ }^{36}$

Kemudian Rasullullah juga menguatkan lagi bahwa pada surat al-Nu>r (31): 24 menjelaskan batas minimal bagi pakaian perempuan yang saat ini kita kenal sebagai

${ }^{35}$ Nahruddin Baidan, Tafsir Bi Al-Ra'yi Upaya Penggalian Konsep Wanita Dalam Al-Qur'an, (Yogyakarta: Pustaka Pelajar 1999), 128-129

${ }^{36}$ Muh \}ammad Qurais Shihab, Jilbab Pakaian Wanita Muslimah, (Jakarta: lentera Hati, 2004),119 
pakaian dalam. Dalam hal ini rasulullah menetapkan batasan maksimal bagi pakaian perempuan dengan sabdanya "kullu al-mar'ah 'aurat ma 'ada wajhiha wa kaffayha" (seluruh tubuh perempuan adalah aurat kecuali wajah dan kedua telapak tangannya). ${ }^{37}$

Oleh karena itu apa yang kita sebut sekarang dengan istilah "pakaian syari'at" sebenarnya ia adalah pakaian orang arab mukminah dan nasrani pada abad ke tujuh masehi. Batas minimal pakaian perempuan mukminah dijelaskan dalam surat al-Nu>r dan berlaku bagi seluruh perempuan mukminat dimuka bumi ini, dimana saja, dan kapan saja. Menurut Shahru>r, perempuan arab mukminah hendaknya memperbaiki pemahaman yang keliru tersebut yang dihasilkan oleh model analogi antara fenomena yang hadir, berupa pakaian seluruh kaum muslimat di muka bumi pada setiap zaman dan tempat, dengan fenomena yang telah hilang berupa pakaian kedaerahan perempuan arab pada abad ke tujuh masehi. Qiya $>s$ semacam ini yang disebut Qiya $>$ s al-Syahid 'Ala $>$ $a l-G h a>i b$ tidak bisa dibenarkan, kecuali jika kita memang menganggap bahwa perempuan arab sebelum diturunkan surat al-Nu>r dan al-Ahzab dalam kondisi telanjang tanpa pakaian. Anggapan itu tentu saja tidak benar. Kita jangan mencampur adukkan antara pakaian yang di syari'atkan oleh Allah dalam kitab-Nya dengan model pakaian kedaerahan yang berlaku dalam masyarakat arab. Pencampuradukkan ini terjadi secara nyata dalam kasus munculnya konsep pakaian syari'at (al-liba>s al-syar'i), sebuah kerancuan yang ditimbulkan oleh model analogi antara hadir dengan yang tidak hadir. Demikian, bahkan hingga saat ini kita hampir tidak bisa membedakan antara pakaian perempuan muslimat mukminat arab dengan muslimat Nasrani yang tinggal di Huran, daerah sebelah utara Syiria. Keduanya mengenakan pakaian yang sama, yaitu pakaian daerah tradisional yang bersifat historis (al-ziyyu al qawmi al-tari>khi>al-taqli>di>).${ }^{38}$

Ada sebagian orang yang mengatakan apakah para Ahli Fiqih tidak mengetahui bahasa arab dan kamilah yang mengetahuinya sekarang? Sesungguhnya kesalahan itu tidak terletak pada bahasa, tetapi merupakan kesalahan metodologis. Ketika para ulama membaca ayat Q.S al-Nu>r 31 dan al-Ahzab:59, pada saat yang sama mereka mereka juga membaca hadits Nabi "kullu al-mar'ah awratun ma 'ada wajhiha wa kaffayha" yang artinya :"seluruh tubuh perempuan adalah aurat kecuali wajah dan telapak tangannya". Mereka beranggapan bahwa hadist ini adalah penjelas bagi ayat tersebut, bukan batas maksimal bagi pakaian perempuan. Padahal hadis ini hanya merupakan

${ }^{37}$ Ibid., 169

38 Muh\}ammad Shahrur, Prinsip dan Dasar Hemeneutika Hukum Islam Kontemporer , (Yogyakarta:eLSAQ Press, 2007), 266 
penjelasan terhadap salah satu sisi ayat tersebut (al-Tarf al-Muqabil). Pada kondisi ini seluruh pengetahuan mereka tentang bahasa arab, baik dalam bidang Fiqhu al-Lughah, Nahwu maupun Sharaf sama sekali tidak bermanfaat. Bahkan akan menjerumuskan mereka dalam kerancuan dan lingkaran masalah yang tak terselesaikan ${ }^{39}$.

Allah memrintahkan perempuan beriman untuk menutup bagian tubuh mereka yang termasuk kategori $a l-j u y u>b$, yaitu perhiasan yang tersembunyi secara fisik dan melarang mereka untuk memperlihatkan bagian tersebut. Hal ini diisyaratkan dalam firman-Nya: wa la yubdina zinatahunna (janganlah mereka menampakkan perhiasan mereka). Penampakan (al-ibda>') hanya dilakukan pada sesuatu yang tersembunyi seperti dalam firman-Nya: in tubdu ma fi anfusikum aw tukhfuhu (Qs. Albaqarah[2]:284). Kata $a l-i b d a>$ ' juga hanya di peruntukkan bagi obyek yang berakal seperti dalam firman-Nya: fa badat lahuma> saw'atuhuma (Qs. Taha [20]:21). Sebagian orang menyangkal pendapat ini dengan menyatakan:'bukankah mulut, hidung,kedua mata,dan kedua telinga termasuk dalam kategori al-juyu>b? Di sini Muh\}ammad Shahru>r menjawab: benar, tetapi bagian-bagian tersebut adalah juyu>b yang tampak karena terletak di wajah. Padahal bagian kepala laki-laki atau perempuan merupakan bagian yang paling menonjol secara fisik yang berfungsi sebagai ciri khas manusia. Sebagian dari wilayah $j u y u>b$ ini di sebut secara eksplisit oleh allah seperti dalam firman-Nya: wa yahfad'na furu> jahunna wa yahfad'na furu> jahunna yang diwajibkan allah agar tidak tampak oleh pandangan mata. Menurut Shahru>r bahwa kemaluan dan pantat perempuan termasuk dalam kategori juyu>b yang tidak boleh disaksikan sepasang mata kecuali oleh suaminya. Bagian inilah yang oleh para ahli fiqih ditetapkan sebagai aurat berat bagi budak perempuan ketika barada dihadapan orang lain, dan aurat berat perempuan merdeka ketika berada dihadapan mahram-nya saja. ${ }^{40}$

Di dalam aurat dibagi menjadi dua, yaitu aurat yang berat (mughalazah) dan aurat ringan (mukhaffafah). Aurat berat bagi laki-laki adalah kemaluan, buah pelir dan daerah pelir, sedangkan aurat ringan selain bagian-bagian itu. Aurat berat bagi perempuan budak sama dengan aurat laki-laki ditambah pantat, dan aurat ringan baginya adalah sama dengan aurat ringan laki-laki. Adapun aurat berat perempuan merdeka adalah seluruh tubuhnya selain bagian kedua tangan, kaki, dan bagian dada.

\footnotetext{
${ }^{39}$ Ibid., 267

${ }^{40}$ Muhammad Shahrur, Metodologi Fiqih Islam Kontemporer, (Yogyakarta: eLSAQ Press, 2008 ),
} 
Bagian-bagian tersebut adalah aurat dalam shalat kemudian bagaimana hukum aurat di luar shalat? Jika merujuk pada kitab-kitab Fiqih Empat Madzhab, kita akan menjumpai pendapat yang menyatakan: "di luar shalat mukallaf harus menutupi auratnya, baik demi kepentingan dirinya maupun orang lain yang tidak halal untuk dilihat auratnya kecuali dalam hal-hal darurat, seperti demi pengobatan misalnya. Batas aurat wanita merdeka di luar shalat, baik dalam kondisi sendirian, bersama muhrimnya, atau bersama perempuan muslimat lainnya adalah bagian antara pusar dan lutut. Adapun jika bersama laki-laki asing atau perempuan non muslim, maka auratnya adalah selururh tubuhnya kecuali" wajah dan dua telapak tangan. Aurat laki-laki di luar shalat adalah bagian tubuh antara pusar dan lutut, selain itu boleh diperlihatkan, khususnya dalam kondisi normal ${ }^{41}$.

Batasan aurat dan kewajiban berjilbab bagi perempuan merupakan hasil pemahaman secara tekstual terhadap al Qur'an dan sunnah. ${ }^{42}$ Dalam surat al-Nu $>$ r ayat 31:

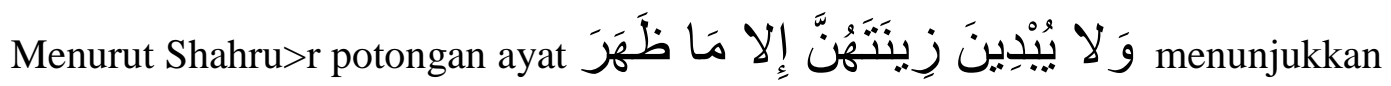
bahwa seluruh tubuh perempuan adalah zinnah (perhiasan). Zinah ini ada dua macam, yakni zinah z \}a $>$ hir (tampak) dan zinnah khafi (tidak tampak). Zinah z \}a $>$ hir adalah bagian yang tampak dari tubuh perempuan, seperti kepala, tangan dan kaki. Inilah yang dimaksud dengan" ماظطر منها". Bagian-bagian ini boleh diperlihatkan kepada orang lain. Adapun zinnah khafi adalah bagian tubuh perempuan yang menjadi privacy bagi dirinya sehingga tidak boleh dilihat orang lain. Yang termasuk kategori zinah khafi dalam ayat tersebut adalah $j u y u>b$. Kata $j u y u>b$ dalam bahasa arab berarti bagian tubuh yang berada diantara dan dibawah payudara, bawah ketiak, kemaluan dan pantat. Bagian-bagian inilah yang harus ditutup, sesuai kalimat

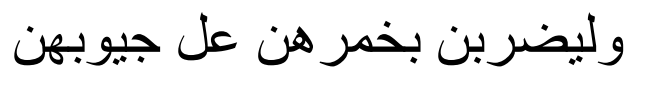

Sementara itu, menurut Shahru>r, Q.S.33:59 hanyalah sebagai ayat ta'li>m (pendidikan tentang etika) berbusana bagi muslimah, dan bukan sebagai ayat tashri> ' yang mewajibkan muslimah berjilbab. ${ }^{43}$ Di dalamnya ditetapkan dua sebab pemberlakuan ajaran tersebut, yaitu pengetahuan dan adanya gangguan. Perempuan

${ }^{41}$ Ibid., 508

${ }^{42}$ Sri Suhandjati Sukri, Pemahaman Islam dan Tantangan Keadilan Jender, (Yogyakarta:Gama Media, 2002), 139

${ }^{43}$ Ibid., 139 
mukminah diwajibkan untuk menutup bagian-bagian tertentu dari tubuhnya yang apabila ditampakkan akan menyebabkan gangguan ( $a l$-aza). Tetapi hal ini diberlakukan dalam kerangka pengajaran, bukan sebagai ketetapan hukum. Gangguan terdiri dari dua macam, yaitu yang bersifat alami dan bersifat sosial. Gangguan alami terkait dengan lingkungan geografis, seperti suhu udara dan cuaca. Perempuan mukminah hendaknya berpakaian sesuai dengan kondisi suhu udara dan cuaca yang ada di tempat tinggalnya sehingga tidak menimbulkan alami pada dirinya. Sebagian orang mengatakan bahwa hal ini bukan masalah penting oleh karena itu tidak disebutkan dalam ayat. ${ }^{44}$ Ayat tersebut memberi pelajaran kepada muslimah agar mengenakan busana luar yang berbentuk jilbab. Busana luar ini sebenarnya bisa berupa celana, kemeja,baju kurung, dan pakaianpakaian lainnya. Semua jenis jenis busana ini masuk dalam kategori jilbab. Bukti bahwa ayat tersebut hanya sebagai ayat ta'li $>\mathrm{m}$ adalah disebutkan alasan pemakaian busana luar, yaitu agar tidak terkena ' $a z \bar{a}$ (bahaya). Artinya ayat tersebut mendidik muslimah agar menutup bagian-bagian tubuhnya yang apabila ditampakkan akan mendatangkan bahaya. Dalam ayat tersebut, 'azō ada dua macam, yakni 'azō tabi'i> (berhubungan dengan alam), dan 'azō ijtima' (berhubungan dengan masyarakat), 'azō tabi'I berhubungan dengan tinggi rendahnya suhu udara setempat. Ayat tersebut mendidik muslimah agar mengenakan busana yang dapat melindungi tubuhnya dari panas dan dinginnya suhu udara tempat dia hidup sehingga tidak sakit, sedangkan 'azā ijtima'I dimaksudkan sebagai celaan dan cercaan masyarakat terhadap model busana yang dikenakan muslimah. Hal ini berarti bahwa ayat tersebut mendidik muslimah agar mengenakan busana luar yang modelnya sesuai dengan adat kesopanan masyarakat setempat sehingga tidak menjdi bahan gunjingan dan cercaan masyarakat. Dengan demikian, ayat itu hanyalah berkaitan dengan pujian dan celaan masyarakat terhadapnya dan tidak ada kaitannya sama sekali dengan pahala dan siksa. ${ }^{45}$

Disini kami paparkan tentang teori batasnya Shahru>r batasan minimal dan batasan maksimal aurat perempuan.

\footnotetext{
${ }^{44}$ Ibid., 261

${ }^{45}$ Ibid., 142
} 


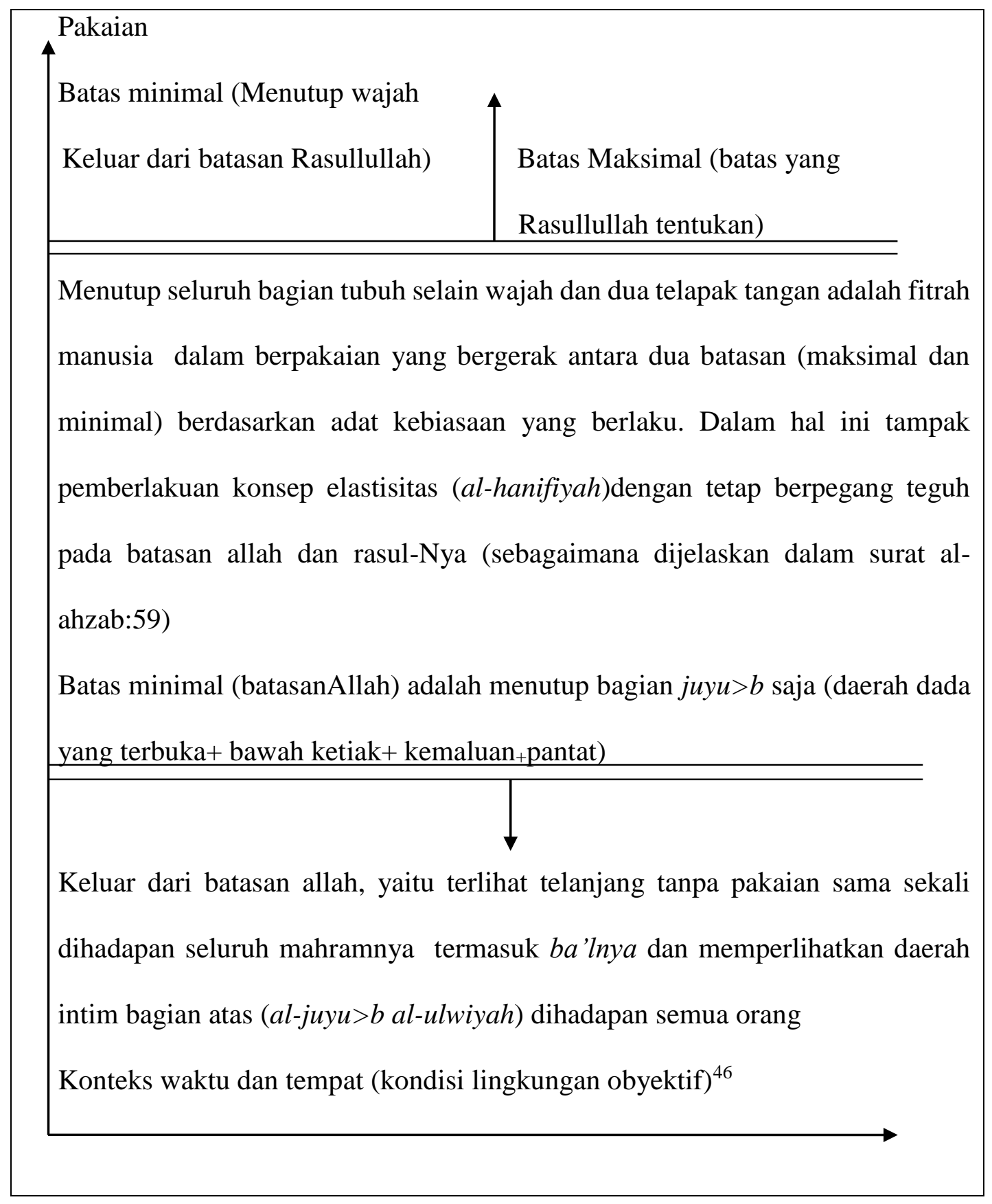

Upaya Shahru>r untuk memberikan batasan aurat maksimal dan minimal perempuan tercakup dalam dua surat, yaitu Q.S al-Nu>r: 31 dan Q.S al-Ahzab:59.

Q.S al-Nu>r: 31 menyatakan batas minimal dari pakaian perempuan dan Rasullullah menyatakan bahwa memperrlihatkan wajah dan tangan adalah batas maksimal berpakaian. Q.S al-Ah\}za>b: 59 memberikan aturan bagaimana perempuan bergerak diantara batas-batas tersebut. Batas minimal menyatakan bahwa tubuh perempuan dapat ditampakkan dalam dua cara: (1) bagian tubuh yang tidak tampak 
secara alamiah. Batas maksimal berpakaian adalah yang hanya memperlihatkan wajah dan tangan. ${ }^{47}$ Batasan ini menyatakan bahwa bertelanjang merupakan pelanggaran terhadap batasan minimal hukum tuhan dan menutup seluruh tubuh termasuk wajah dan tangan adalah ternasuk keluar dari batasan maksimal hukum rasullullah. Oleh karena itu, mayoritas perempuan dunia sudah berpakaian dengan cara yang berada di dalam batasbatas tersebut. ${ }^{48}$

\section{Kesimpulan}

Dalam analisisnya terhadap wahyu Tuhan, sebagaiman tertuang dalam karya monumentalnya Al-Qur'an wa Al-Kitab, Shahru>r menggunakan pendekatan "linguistik modern". Muhammad Shahru>r membagi Toeri batasnya menjadi enam bagian: Pertama Posisi batas minimal ( $h a>$ lah al-had al-adna), Kedua Posisi batas maksimal (ha>lah alhad al-a'la>), Ketiga Posisi batas maksimal dan minimal bersamaan (ha>lah al-had ala'la $>$ wa al-adna> ma'an), Keempat Posisi batas lurus (ha>lah al-mustaqi $>m$ ), Kelima Posisi batas maksimal cenderung mendekat tanpa persentuhan ( $h a>l a h$ al-had-a'la likha>t al-muqari>b du>nal mamas bi al-ha>d al-adna> abadan),Keenam Posisi batas maksimal positif dan batas minimal negatif (ha>lah al-had al-a'la> mujaban wa aladna > saliban)

Disini yang dimaksud batas minimal aurat menurut Muhammad Shahrur yaitu berpakaian yang menutupi bagian juyub saja (daerah dada yang terbuka + bawah ketiak + kemaluan + pantat), sedangkan batas maksimalnya berpakaian yang menutupi seluruh bagian tubuh selain wajah dan kedua telapak tangan. Jika melebihi dari batas maksimal dan batas minimal yang ditentukan oleh Allah maka dianggap melanggar hukum allah. Sedangkan kandungan dari surat maksimal dan batas minimal yang ditentukan oleh Allah maka dianggap melanggar hukum allah. Sedangkan kandungan dari surat Al-Ahzab ayat 59 hanyalah sebagai ayat pengajar bukan ayat tasyri, jadi ayat ini bukan ketentuan hukum yang wajib dijalankan.

47 Muh \}ammad Shahrur, Prinsip dan Dasar Hermeneutika Hukum Islam Kontemporer , (Yogyakarta: eLSAQ Press, 2007),297

${ }^{48}$ Ibid., 298 


\section{Daftar Pustaka}

Al-Hasyimi Muhammad Ali. Muslimah Ideal Pribadi Islami Dalam al-Qur'an dan asSunnah. Yogyakarta: Mitra Pustaka; 2004.

Al-Maraghi Ahmad Mustafa. Tafsir al-Maraghi. Semarang: Toha Putra Semarang; 1992

Arikunto Suharsimi. Prosedur Penelitian suatu Pendekatan Praktek. Jakarta: Rineka Cipta, 1990.

Baidan Nashruddin. Tafsir Bi Al-Ra'yi Upaya Penggalian Konsep Wanita Dalam AlQur'an. Yogyakarta:Pustaka Pelajar; 1999.

Fadhlullah Sayid Muhammad Husain. Dunia Wanita dalam Islam. Jakarta:Lentera Basritama; 2000

Ilyas Yunahar. Tafsir Tematis Cakrawala Al-Qur'an . Yogyakarta: Suara Muhammadiyah; 2003

Mughniyah Muhammad Jawad. Fiqih Lima Madzhab:Ja'fari, Hanafi, Malki, Syafi'i, Hambali. Jakarta: PT. Lentera Basritama; 1996

Nawawi Hadari. Penelitian Terapan. Yogyakarta: Gadjah Mada University Pers; 1994

Nasif, Umar Fatima. Menggugat Sejarah Perempuan:Mewujudkan Gender Sesuai Tuntunan Islam. Jakarta: Cendekia Sentra Muslim; 2001.

Ridwan, Muhammad Shahru. Limitasi Hukum Pidana Islam . Semarang: Walisongo Press; 2008.

Sukri Sri Suhandjati. Pemahaman Islam dan Tantangan Keadilan Jender. Yogyakarta:Gama Media; 2002.

Shahrur Muhammad. Prinsip dan Dasar Hermeneutika Hukum Islam Kontemporer. Yogyakarta: eLSAQ Press; 2007.

Syahrur Muhammad. Metodologi Fiqih Islam Kontemporer. Yogyakarta:Elsaqpress; 2008

Shihab Muhammad Quraish. Wawasan al-Qur'an:Tafsir Maudhu'i atas Pelbagai Persoalan Umat. Bandung: Mizan Media Utama; 2001.

Shihahb Quraish. Jilbab,Pakaian Wanita Muslima. Jakarta: lentera Hati; 2004.

Syuqqah Abu, Busana dan Perhiasan Wanita Menurut Al-Qur'an Dan Hadis. Bandung: Al-Bayan; 1995

Wijaya Aksin. Teori Interpretasi al-Quran Ibnu Rusyd. Yogyakart: Lkis Printing Cemerlang; 2009 